\title{
SISTEM INFORMASI AUDIT MUTU INTERNAL (SIAMI)
}

\author{
Andie $^{1)}$, Muhammad Hasbi ${ }^{2}$, Hasanuddin ${ }^{3)}$ \\ ${ }^{1}$ Fakultas Teknologi Informasi, Universitas Islam Kalimantan Muhammad Arsyad Al Banjari Banjarmasin \\ Email : andina777@gmail.com \\ ${ }^{2}$ Fakultas Teknologi Informasi, Universitas Islam Kalimantan Muhammad Arsyad Al Banjari Banjarmasin \\ Email : mhasbi.mm@gmail.com \\ ${ }^{2}$ Fakultas Teknologi Informasi, Universitas Islam Kalimantan Muhammad Arsyad Al Banjari Banjarmasin \\ Email : hasan.uniska @gmail.com
}

\begin{abstract}
Abstrack
Audit Mutu Internal adalah proses pengujian yang sistematik, mandiri, dan terdokumentasi untuk memastikan pelaksanaan kegiatan di PT sesuai prosedur dan hasilnya telah sesuai dengan standar untuk mencapai tujuan institusi. Pada saat ini proses Audit Mutu Internal di Universitas Islam Kalimantan Muhammad Arsyad Al Banjarmasin dilaksanakan secara manual dan paperless. Tahap pertama Panitia yang dibentuk dari Lembaga Penjaminan Mutu UNISKA menyusun data Auditor dan Auditee yang selanjutnya akan dibagi dan dipasangkan. Kemudian dilaksanakan rapat persiapan AMI guna menyamakan persepsi terhadap Auditor terhadap instrumen-instrumen yang telah disiapkan panitia. Pada hari pelaksanaan, Auditor langsung mendatangi Auditee (Program Studi) untuk melaksanakan pencocokkan data yang ada di Program Studi. Apabila selesai maka Auditor harus membuat laporan AMI berdasarkan hasil kunjungan ke Program Studi. Rapat Tinjauan Manajemen dilaksanakan terhadap masing-masing Prodi guna menindaklanjuti Temuan dari hasih Audit yang dihadiri pihak-pihak terkait termasuk Rektor dan Yayasan. Akhirnya Auditor menyusun kembali laporan akhir berdasarkan hasil Rapat Tinjauan Manajemen yang telah dilaksanakan. Semua sistem yang dilakukan secara manual sebaiknya harus dibuatkan sistem secara otomatis berupa aplikasi guna memudahkan setiap prosesnya. Oleh karena itu semua proses yang telah dilaksanakan diatas akan diperbaiki dengan cara membuat sebuah Sistem Informasi Audit Mutu Internal (SIAMI) dimana pada sistem nantinya akan sangat memudahkan Auditor, Auditee, maupun Panitian pelakana dalam melaksanakan semua proses dalam Audit Mutu Internal (AMI) di Universitas Islam Kalimantan Muhammad Arsyad Al Banjari Banjarmasin.
\end{abstract}

Kata kunci: sistem, informasi, ami, audit, internal, web

\section{PENDAHULUAN}

Audit Mutu Internal adalah proses pengujian yang sistematik, mandiri, dan terdokumentasi untuk memastikan pelaksanaan kegiatan di PT sesuai prosedur dan hasilnya telah sesuai dengan standar untuk mencapai tujuan institusi. Audit Mutu bukanlah asesmen/penilaian melainkan pencocokan kesesuaian antara pelaksanaan dengan perencanaan suatu kegiatan/program. (Tim, 2018)

Audit internal adalah Audit yang dilakukan untuk menentukan tingkat kesesuaian pelaksanaan kegiatan terhadap standar mutu organisasi sendiri (standar Internal), Peraturan, Prosedur, Instruksi kerja. Sedangkan Audit eksternal adalah Audit yang dilakukan untuk menentukan tingkat kesesuaian terhadap standar eksternal.
Bab III Pasal 52 Undang-Undang Nomor 12 tahun 2012 tentang Pendidikan Tinggi (1) Penjaminan Mutu Pendidikan Tinggi merupakan kegiatan sistemik untuk meningkatkan mutu pendidikan tinggi secara berencana dan berkelanjutan. (2) Penjaminan mutu sebagai mana dimaksud pada ayat (1) dilakukan melalui penetapan, pelaksanaan, evaluasi, pengendalian, dan peningkatan standar pendidikan tinggi.

Pasal 5 ayat (1) Permenristek dikti No. 62 Tahun 2016 Tentang SPM Dikti

(1) SPMI memiliki siklus kegiatan yang terdiri atas : a. Penetapan Standar Pendidikan Tinggi; b. Pelaksanaan Standar Pendidikan Tinggi; c. Evaluasi pelaksanaan Standar Pendidikan Tinggi d. Pengendalian pelaksanaan Standar Pendidikan Tinggi; dan e. Peningkatan Standar Pendidikan Tinggi. 
(2) Evaluasi sebagai mana dimaksud dalam ayat (1) huruf c dilakukan melalui Audit Mutu Internal.

Tujuan Audit Mutu Internal Memastikan implementasi sistem manajemen sesuai dengan sasaran/tujuan Mengidentifikasi peluang perbaikan sistem manajemen mutu Mengevaluasi efektivitas penerapan sistem manajemen mutu Memastikan sistem manajemen memenuhi standar/regulasi.

Audit Mutu Internal (AMI) di Universitas Islam Kalimantan Muhammad Arsyad Al Banjari Banjarmasin dilaksanakan setiap tahun sekali, dan setiap tahunnya dinamakan siklus. Pada tahun 2019 Universitas Islam Kalimantan Muhammad Arsyad Al Banjari Banjarmasin sudah melaksanakan sampai siklus ke-4. Pada AMI siklus ke-4 dilaksanakan dengan jumlah Auditor sebanyak 42 orang terhadap Audite (Program Studi) sebanyak 23 prodi.

Pada saat ini proses Audit Mutu Internal di Universitas Islam Kalimantan Muhammad Arsyad Al Banjarmasin dilaksanakan secara manual dan paperless. Tahap pertama Panitia yang dibentuk dari Lembaga Penjaminan Mutu UNISKA menyusun data Auditor dan Auditee yang selanjutnya akan dibagi dan dipasangkan. Kemudian dilaksanakan rapat persiapan AMI guna menyamakan persepsi terhadap Auditor terhadap instrumen-instrumen yang telah disiapkan panitia. Pada hari pelaksanaan, Auditor langsung mendatangi Auditee (Program Studi) untuk melaksanakan pencocokkan data yang ada di Program Studi. Apabila selesai maka Auditor harus membuat laporan AMI berdasarkan hasil kunjungan ke Program Studi. Rapat Tinjauan Manajemen dilaksanakan terhadap masingmasing Prodi guna menindaklanjuti Temuan dari hasih Audit yang dihadiri pihak-pihak terkait termasuk Rektor dan Yayasan. Akhirnya Auditor menyusun kembali laporan akhir berdasarkan hasil Rapat Tinjauan Manajemen yang telah dilaksanakan.

Semua proses diatas sangat memerlukan waktu yang lama dan sangat merepotkan bagi Auditor. Hal lain lagi adalah tidak konsistennya format pelaporan Audit, padahal sudah disediakan format wordnya. Banyak dari Auditor yang membuat format sendiri baik isian ketidaksesuaian maupun format lainnya.

Semua sistem yang dilakukan secara manual sebaiknya harus dibuatkan sistem secara otomatis berupa aplikasi guna memudahkan setiap prosesnya. (Andie, Hasanuddin, \& Fikri, 2018) Oleh karena itu semua proses yang telah dilaksanakan diatas akan diperbaiki dengan cara membuat sebuah Sistem Informasi Audit Mutu Internal (SIAMI) dimana pada sistem nantinya akan sangat memudahkan Auditor, Auditee, maupun Panitian pelakana dalam melaksanakan semua proses dalam Audit Mutu Internal (AMI) di Universitas Islam Kalimantan Muhammad Arsyad Al Banjari Banjarmasin.

\section{METODE PENELITIAN}

Langkah-langkah dalam pembuatan sistem ini menggunakan metode waterfall.

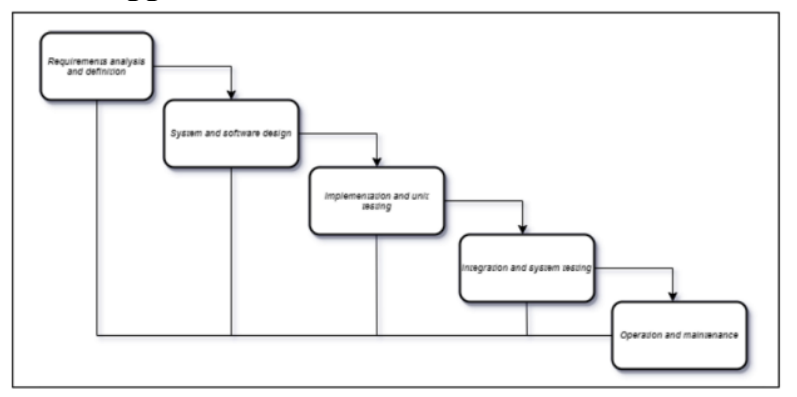

Gambar 1 Metode Waterfall

Kelebihan metode ini memungkinkan departementalisasi dan kontrol. Adapun tahapan yang ada pada metode sebagai berikut :

a. Analisis Kebutuhan (Requirement Analisis)

Penelitian ini dilakukan anilisis kebutuhan sistem dengan cara wawancara langsung dengan staf Lembaga Penjaminan Mutu Uniska untuk mengetahui alur pelaksanaan AMI, melakukan studio dokumen pada berbagai jurnal terkait yang di Perlukan untuk disesuaikan atau di tambahkan ke sistem yang akan dibangun agar menghasilkan sistem yang diinginkan.

b. Desain Sistem (System Design)

Setelah mendapatkan kebutuhan sistem dalam tahapan sebelumnya maka dilanjutkan dengan merancang tampilan sistem dan menentukan software pendukung sistem. Design sistem dikerjakan mengguanakan aplikasi Power designer dan Balsamiq Markup.

c. Implementasi (Implementation)

Pada tahap ini, melakukan implementasi pengkodingan Front-end dan Back-end serta logika-logika sistem sesuai dengan rancangan sistem yang telah ditentukan sebelumnya. Proses koding dilakukan 
mengunakan software Adobe Dreamweaver CS5.5 dan Sublime Text 3.

d. Integrasi Pengujian (Integration and Testing) Kemudian setelah aplikasi siap digunakan maka dilanjutkan dengan pengujian seluruh sistem untuk mengecek setiap kegagalan maupun kesalahan dari keseruhan berupa CRUD (Tambah, Menampilkan, Ubah, dan Hapus data). Pengujian ini dilakukan dengan metode Blackbox.

e. Operasi dan Pemeliharaan (Operation and Maintenance)

Tahap terakhir melaukan pemeliharaan atau perbaikan kesalahan sistem jika dalam proses pengujian sebelumnya ditemukan adanya error atau ketidaksesuaian dengan yang diharapkan.

\section{Tahapan Pembuatan Sistem}

Sistem Informasi Audit Mutu Internal (SIAMI) di rancang menggunakan aplikasi Power Designer sedangkan pembuatan aplikasi ini menggunakan bahasa pemrograman PHP dan MySQL sebagai pengelola databasenya dan rancangan antarmukanya menggunakan Fremwork Bootstrap. Berikut beberapa tahapan dalam pembuatan Sistem Informasi ini :

\section{a. Rancangan Menu}

Berikut rancangan menu yang akan di terapkan di aplikasi. Terdapat 3 level user yaitu Auditor, Auditee dan Admin.

Tabel 1 Rancangan Menu

\begin{tabular}{|c|c|c|}
\hline Level User & Menu & Sub Menu \\
\hline \multirow[t]{8}{*}{ Auditor } & AMI & Mekanisme \\
\hline & & Audit \\
\hline & & Kesimpulan \\
\hline & & Perbaikan \\
\hline & & Tanggal RTM \\
\hline & & Laporan AMI \\
\hline & Profile & \\
\hline & Logout & \\
\hline \multirow[t]{4}{*}{ Auditee } & AMI & Ubah Status \\
\hline & & Laporan AMI \\
\hline & Profile & \\
\hline & Logout & \\
\hline \multirow[t]{6}{*}{ Admin } & Home & \\
\hline & User & Fakultas \\
\hline & & Prodi \\
\hline & & Auditor \\
\hline & & Admin \\
\hline & AMI & AMI \\
\hline
\end{tabular}

\begin{tabular}{|l|l|l|}
\hline & & Standar \\
\hline & & KTS \\
\hline & Siklus \\
\hline & Report & Rekap Temuan \\
\hline & Persentasi KTS \\
\hline My & \\
\hline Profile & \\
\hline Logout & \\
\hline
\end{tabular}

\section{b. Rancangan Database}

Database dirancang dan dibuat menggunakan aplikasi PHPMyAdmin databasenya sendiri berbasis MySQL. Berikut rancangan database yang akan dibuat:

1) Tabel ami_admin

Tabel 2 Tabel ami_admin

\begin{tabular}{|l|l|l|}
\hline \multicolumn{1}{|c}{ Field } & \multicolumn{1}{c|}{ Type } & Null \\
\hline id & int(11) & No \\
\hline nmadmin & varchar(150) & No \\
\hline jabatan & $\operatorname{varchar}(100)$ & No \\
\hline email & $\operatorname{varchar}(150)$ & Yes \\
\hline nidn & varchar(10) & No \\
\hline password & varchar(200) & No \\
\hline foto & text & Yes \\
\hline siklus & int $(11)$ & Yes \\
\hline
\end{tabular}

2) Tabel ami_ami

\begin{tabular}{|l|l|l|}
\multicolumn{3}{c}{ Tabel 3 Tabel ami_ami } \\
\hline id & int(11) & No \\
\hline id_fakultas & int(11) & No \\
\hline id_prodi & int(11) & No \\
\hline kaprodi & varchar(150) & Yes \\
\hline nidn_ketua & varchar(10) & No \\
\hline anggota1 & varchar(200) & No \\
\hline anggota2 & varchar(200) & Yes \\
\hline id_siklus & int(11) & No \\
\hline status & varchar(10) & Yes \\
\hline tgl_rtm & varchar(20) & Yes \\
\hline
\end{tabular}

3) Tabel ami_audit

Tabel 4 Tabel ami_audit

\begin{tabular}{|l|l|l|}
\hline \multicolumn{1}{|c|}{ Field } & \multicolumn{1}{c|}{ Type } & Null \\
\hline id & int(11) & No \\
\hline id_ami & int(11) & No \\
\hline id_prodi & int(11) & No \\
\hline nidn_auditor & $\operatorname{varchar}(10)$ & No \\
\hline stn & varchar(100) & No \\
\hline standar & text & No \\
\hline temuan & varchar(20) & No \\
\hline uraian & text & No \\
\hline
\end{tabular}




\begin{tabular}{|l|l|l|}
\hline tindakan & text & No \\
\hline target & text & No \\
\hline siklus & int(11) & No \\
\hline tgl_audit & varchar(20) & No \\
\hline inputer & varchar(150) & No \\
\hline
\end{tabular}

4) Tabel ami_auditor

Tabel 5 Tabel ami_auditor

\begin{tabular}{|l|l|l|}
\hline \multicolumn{1}{|c|}{ Field } & \multicolumn{1}{c|}{ Type } & Null \\
\hline fakultas & varchar(100) & No \\
\hline auditor & varchar(200) & No \\
\hline nidn & varchar(10) & No \\
\hline niknip & varchar(20) & Yes \\
\hline telp & varchar(15) & Yes \\
\hline email & varchar(200) & Yes \\
\hline foto & text & Yes \\
\hline password & varchar(100) & No \\
\hline siklus & $\operatorname{int}(11)$ & Yes \\
\hline
\end{tabular}

5) Tabel ami_audit_lanjut

Tabel 6 Tabel ami_audit_lanjut

\begin{tabular}{|c|c|c|}
\hline Field & Type & Null \\
\hline id & $\operatorname{int}(11)$ & No \\
\hline id_ami & $\operatorname{int}(11)$ & No \\
\hline id_prodi & $\operatorname{int}(11)$ & No \\
\hline nidn_auditor & $\operatorname{varchar}(10)$ & No \\
\hline standar & text & No \\
\hline temuan & $\operatorname{varchar}(20)$ & No \\
\hline uraian & text & No \\
\hline tindakan & text & No \\
\hline target & text & No \\
\hline verifikasi & $\operatorname{varchar}(20)$ & Yes \\
\hline status & $\operatorname{varchar}(15)$ & Yes \\
\hline tgl_audit & $\operatorname{varchar}(20)$ & No \\
\hline tgl_verifikasi & $\operatorname{varchar}(20)$ & Yes \\
\hline inputer & $\operatorname{varchar}(150)$ & No \\
\hline
\end{tabular}

6) Tabel ami_fakultas

Tabel 7 Tabel ami_fakultas

\begin{tabular}{|l|l|l|}
\hline \multicolumn{1}{|c|}{ Field } & \multicolumn{1}{c|}{ Type } & Null \\
\hline id & int(11) & No \\
\hline dekan & varchar(100) & No \\
\hline nidn & varchar(100) & No \\
\hline niknip & varchar(10) & No \\
\hline telp & varchar(15) & Yes \\
\hline email & Yarchar(200) & Yes \\
\hline foto & text & Yes \\
\hline password & varchar(100) & No \\
\hline siklus & int(11) & Yes \\
\hline
\end{tabular}

7) Tabel ami_kesimpulan

Tabel 8 Tabel ami_kesimpulan

\begin{tabular}{|l|l|l|}
\hline \multicolumn{1}{|c|}{ Field } & \multicolumn{1}{c}{ Type } & \multicolumn{1}{c|}{ Null } \\
\hline id & int $(11)$ & No \\
\hline id_ami & int(11) & No \\
\hline ckp_lengkap & varchar(10) & No \\
\hline sebutkan & text & Yes \\
\hline
\end{tabular}

8) Tabel ami_kts

Tabel 9 Tabel ami_kts

\begin{tabular}{|l|l|l|} 
id & \multicolumn{1}{c}{ Type } & Null \\
\hline kts & int(11) & No \\
\hline ket & varchar(20) & No \\
\hline & text & Yes \\
\hline
\end{tabular}

9) Tabel ami_mekanisme

Tabel 10 Tabel ami_mekanisme

\begin{tabular}{|l|l|l|}
\hline \multicolumn{1}{|c}{ Field } & \multicolumn{1}{c|}{ Type } & Null \\
\hline id & int(11) & No \\
\hline id_ami & int(11) & No \\
\hline question1 & varchar(5) & No \\
\hline question2 & varchar(5) & No \\
\hline question3 & varchar(5) & No \\
\hline question4 & varchar(5) & No \\
\hline question5 & varchar(5) & No \\
\hline question6 & varchar(5) & No \\
\hline
\end{tabular}

10)Tabel ami_prodi

Tabel 11 Tabel ami_prodi

\begin{tabular}{|l|l|l|}
\multicolumn{1}{|c|}{ Field } & \multicolumn{1}{c|}{ Type } & Null \\
\hline id_prodi & int(11) & No \\
\hline id_fakultas & int(11) & No \\
\hline prodi & varchar(100) & No \\
\hline jenjang & varchar(10) & No \\
\hline kaprodi & varchar(200) & No \\
\hline nidn & varchar(10) & No \\
\hline niknip & varchar(20) & Yes \\
\hline telp & varchar(15) & Yes \\
\hline email & varchar(200) & Yes \\
\hline foto & text & Yes \\
\hline password & $\operatorname{varchar}(100)$ & No \\
\hline siklus & $\operatorname{int}(11)$ & Yes \\
\hline
\end{tabular}

11)Tabel ami_siklus

Tabel 12 Tabel ami_siklus

\begin{tabular}{|l|l|l|}
\hline \multicolumn{1}{|c|}{ Field } & \multicolumn{1}{c|}{ Type } & Null \\
\hline id & $\operatorname{int}(11)$ & No \\
\hline tahun & year(4) & No \\
\hline
\end{tabular}


12)Tabel ami_standar

Tabel 13 Tabel ami_standar

\begin{tabular}{|l|l|l|}
\multicolumn{1}{c}{ Field } & \multicolumn{1}{c}{ Type } & \multicolumn{1}{c}{ Null } \\
\hline id & int(11) & No \\
\hline sm_standar & text & No \\
\hline ket & text & Yes \\
\hline
\end{tabular}

\section{c. Relasi Antar Tabel}

Berikut relasi antar tabel yang terbentuk dari Sistem Informasi Audit Mutu Internal (SIAMI) menurut rancangan tabel diatas:

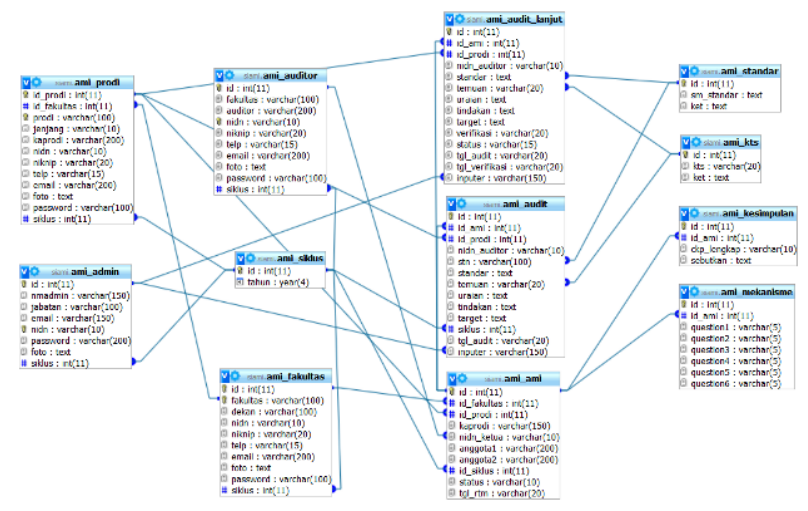

Gambar 2 Relasi Antar Tabel

\section{d. Diagram Konteks}

Berikut diagram konteks yang terbentuk dari rancangan Sistem Informasi Audit Mutu Internal (SIAMI):

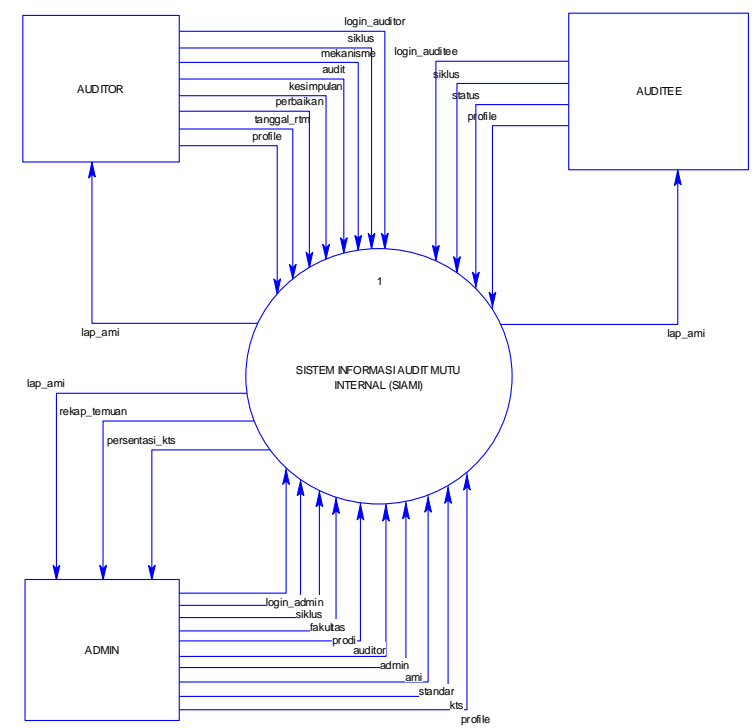

Gambar 3 Diagram Konteks

\section{e. Data Flow Diagram (DFD)}

Berikut Data Flow Diagram (DFD) level 0 yang terbentuk dari rancangan Sistem Informasi Audit Mutu Internal (SIAMI):

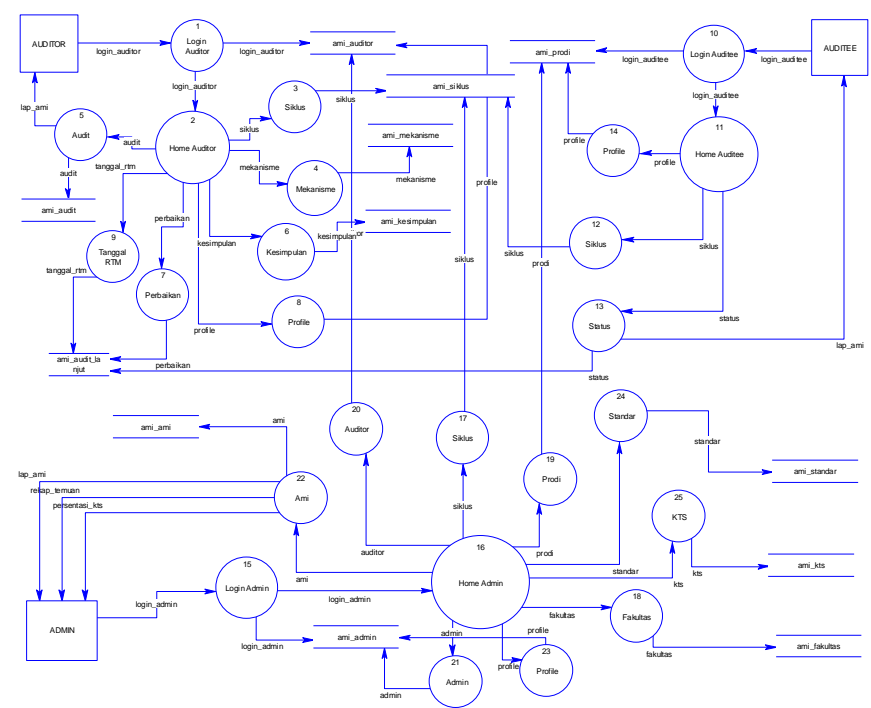

Gambar 4 Data Flow Diagram (DFD) level 0

\section{f. Rancangan Tampilan}

Berikut beberapa contoh rancangan tampilan antar muka dari Sistem Informasi Audit Mutu Internal (SIAMI):

1) Halaman Level User

Pada halaman ini user harus memilih level user terlebih dahulu sesuai akun yang dimilikinya.

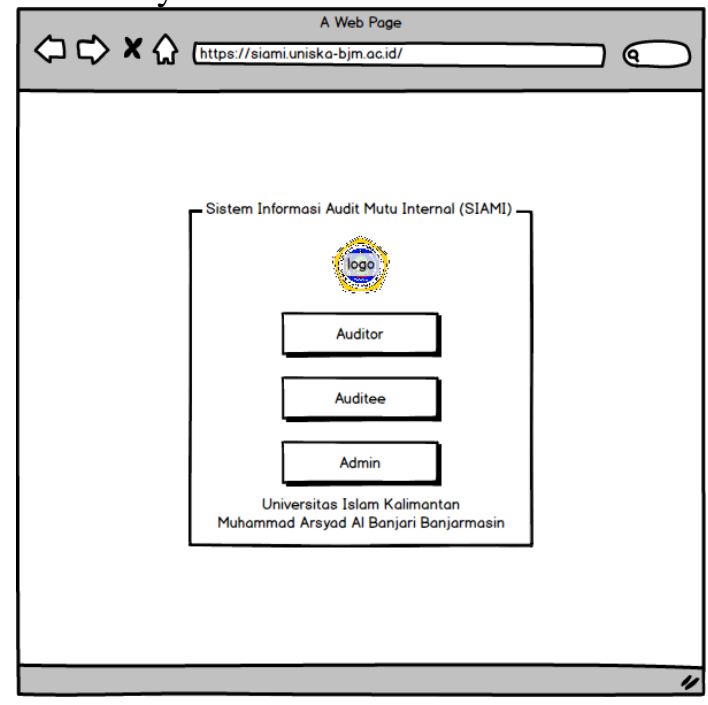

Gambar 5 Rancangan Tampilan Halaman Level User 
2) Halaman Login

Pada halaman ini user memasukkan NIDN dan password yang sudah di berikan oleh admin.

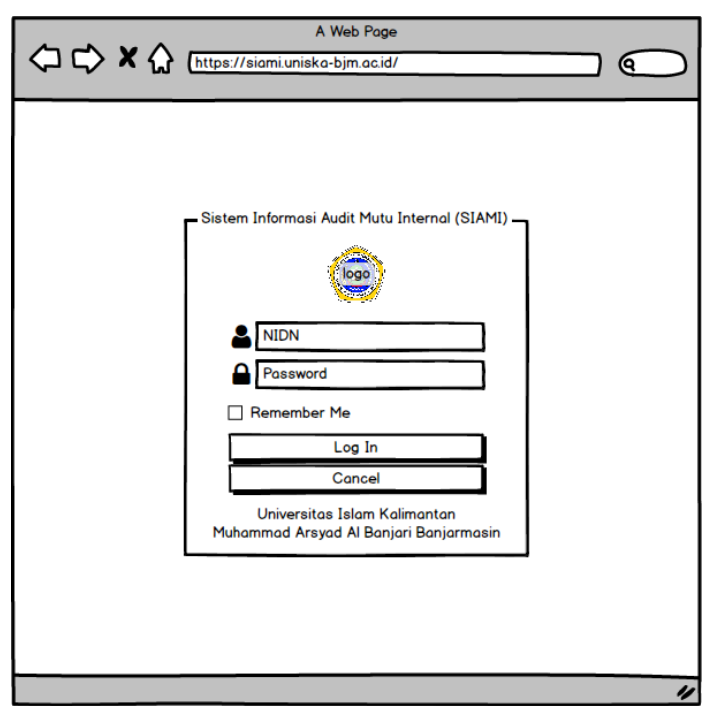

Gambar 6 Rancangan Tampilan Halaman Login

\section{3) Halaman Pemilihan Siklus}

Setelah berhasil login maka user harus memilih siklus mana yang akan dikelolanya.

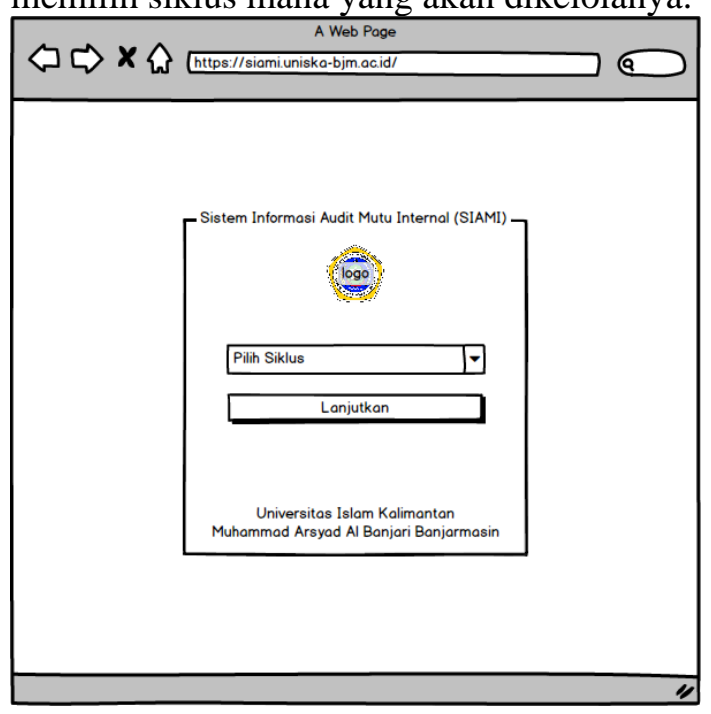

Gambar 7 Rancangan Tampilan Halaman Pemilihan Siklus

4) Halaman Home Auditor

Pada halaman ini Auditor dapat memilih menu dan mengelola semua konten yang disediakan di aplikasi.

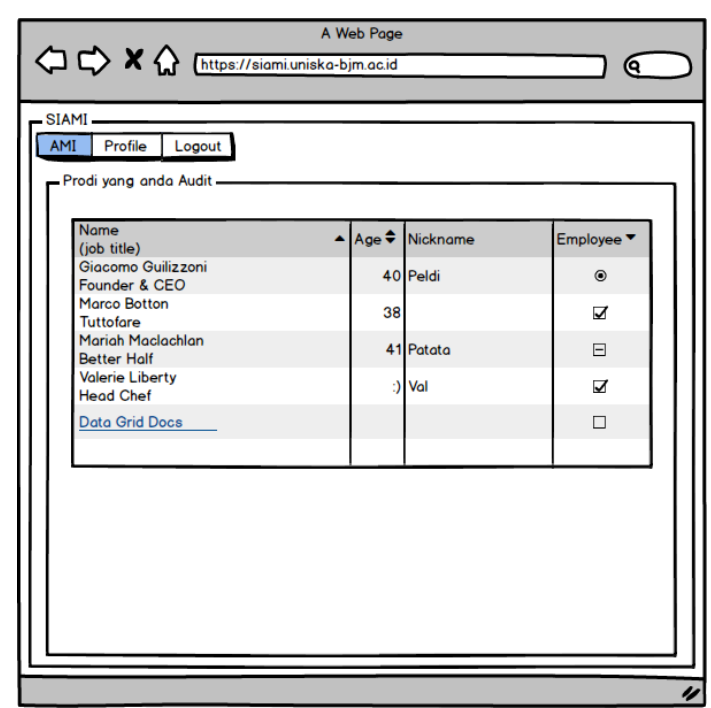

Gambar 8 Rancangan Tampilan Halaman Home Auditor

5) Halaman Home Auditee

Pada halaman ini Auditee dapat memilih menu dan mengelola semua konten yang disediakan di aplikasi.

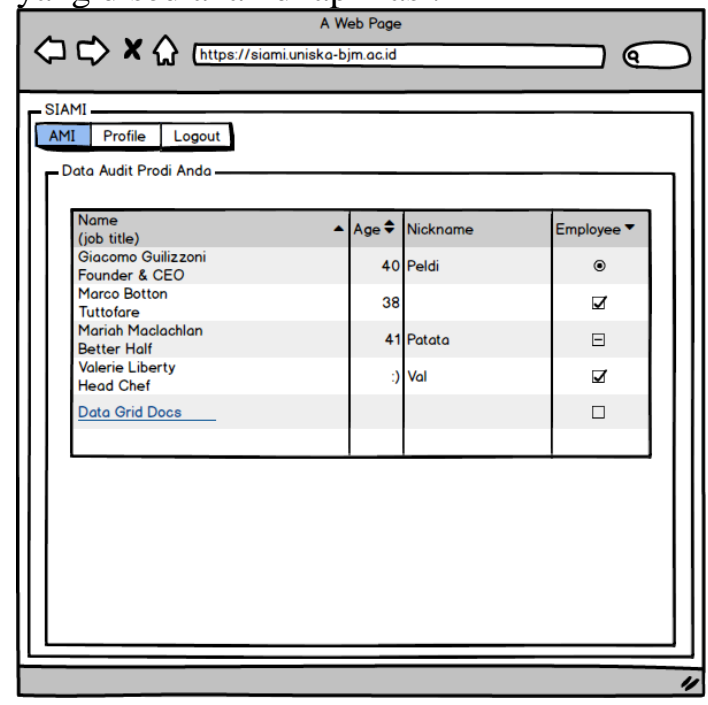

Gambar 9 Rancangan Tampilan Halaman Home Auditee

\section{6) Halaman Home Admin}

Pada halaman ini Admin dapat memilih menu dan mengelola semua konten yang disediakan di aplikasi. 


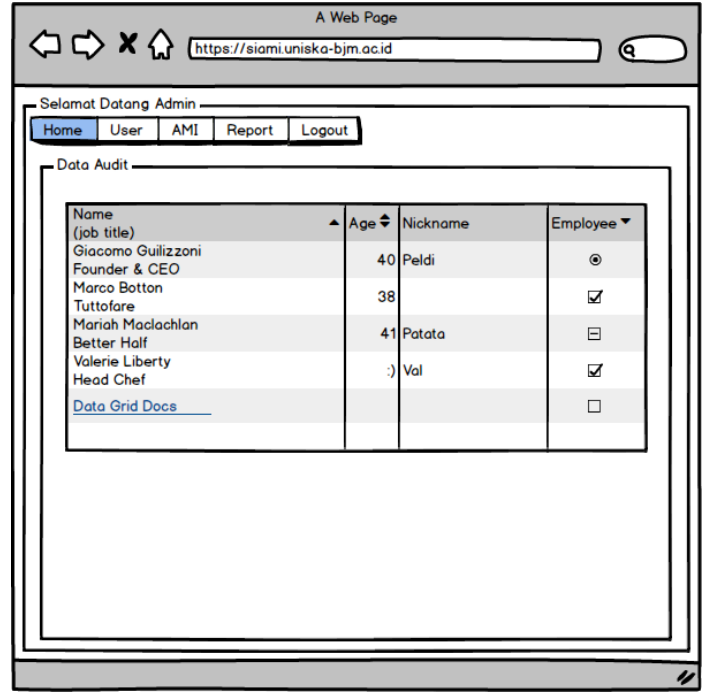

Gambar 10 Rancangan Tampilan Halaman Home Admin

\section{g. Rancangan Output dan Laporan}

Berikut contoh output laporan dari rancangan Sistem Informasi Audit Mutu Internal (SIAMI):

\section{1) Laporan Ami}

Pada halaman ini user dapat melihat dan mencetak laporan ami yang otomatis dibuat berdasarkan data AMI yang sudah diinput oleh Auditor.

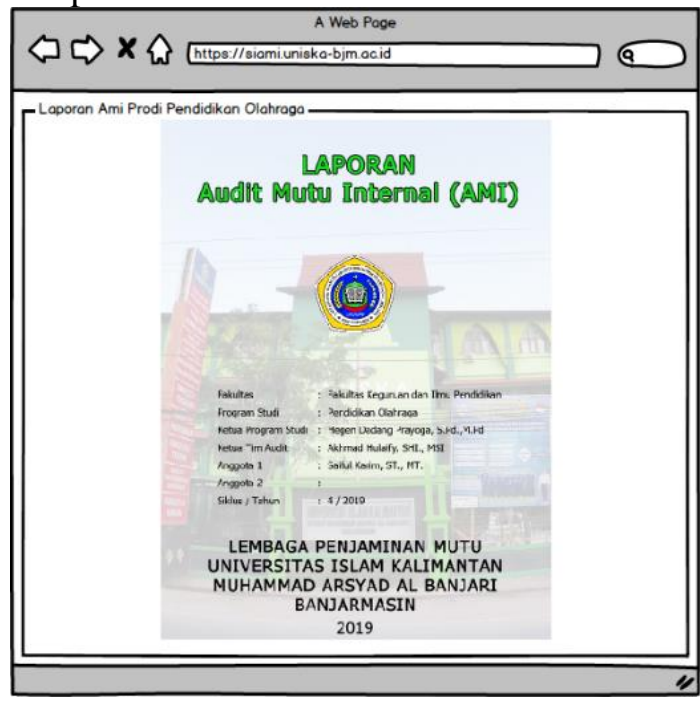

Gambar 11 Rancangan Tampilan Laporan AMI

\section{2) Rekap Temuan}

Pada halaman ini admin dapat melihat rekap data temuan per siklus dan juga grafiknya.

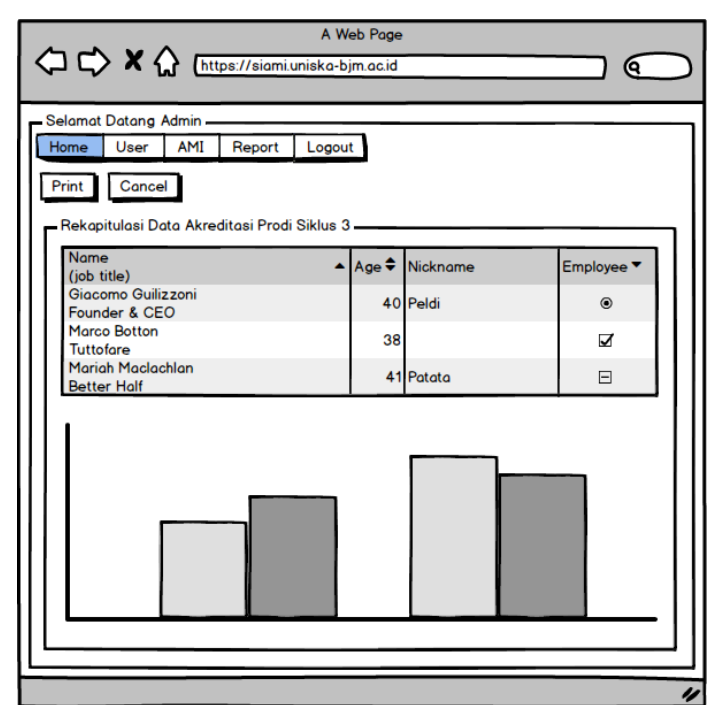

Gambar 12 Rancangan Tampilan Halaman Rekap Temuan

\section{3) Persentasi KTS}

Pada halaman ini admin dapat melihat rekap data persentasi KTS per siklus dan juga grafiknya.

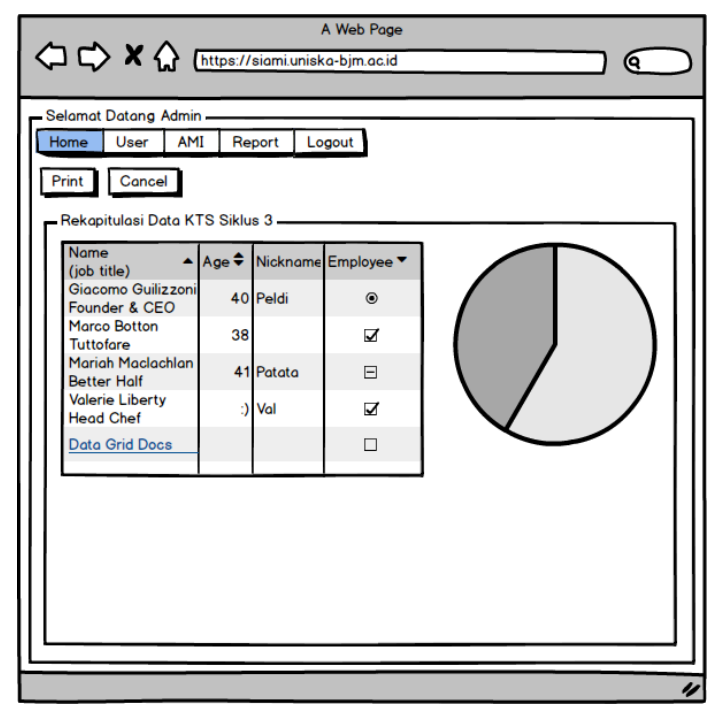

Gambar 13 Rancangan Tampilan Halaman Persentasi KTS

\section{HASIL DAN PEMBAHASAN}

Berikut tampilan aplikasi setelah selesai pengerjaan keseluruhan dan setelah dilakukan uji coba dan perbaikan sistem. 
a. Halaman Level User

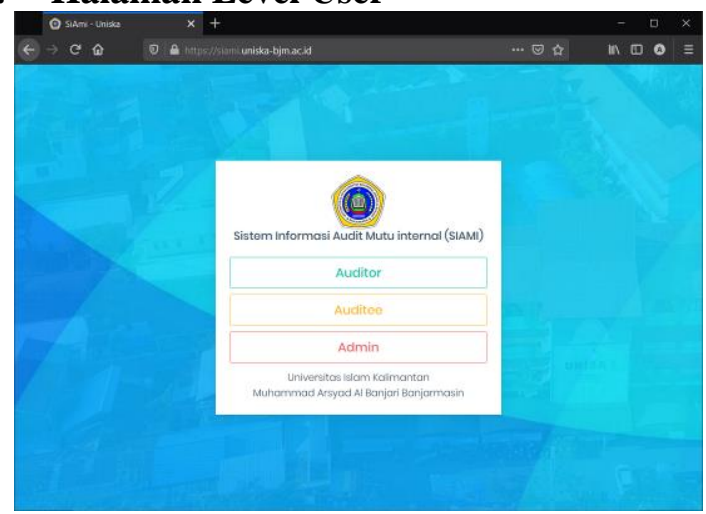

Gambar 14 Halaman Level User

\section{b. Halaman Login}

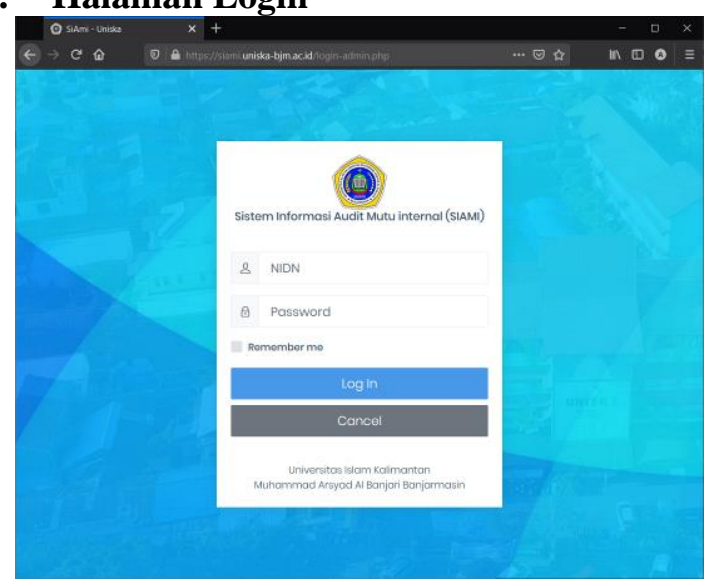

Gambar 15 Halaman Login

\section{c. Halaman Pemilihan Siklus}

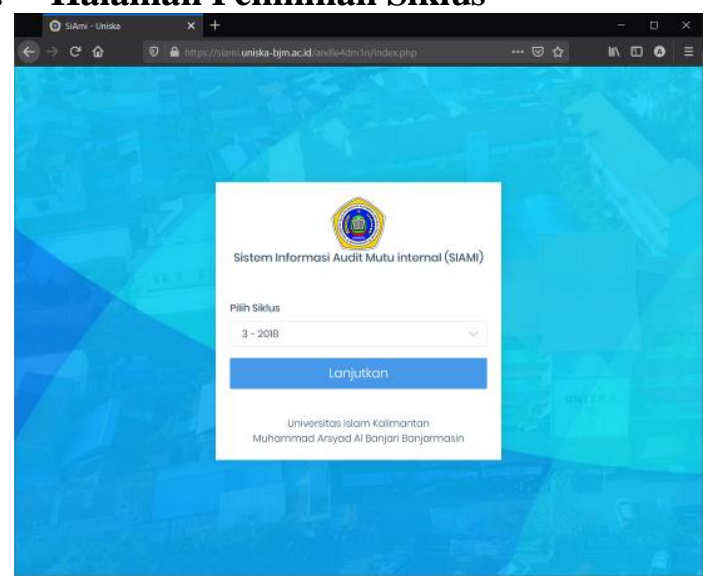

Gambar 16 Halaman Pemilihan Siklus

\section{d. Halaman Home Auditor}

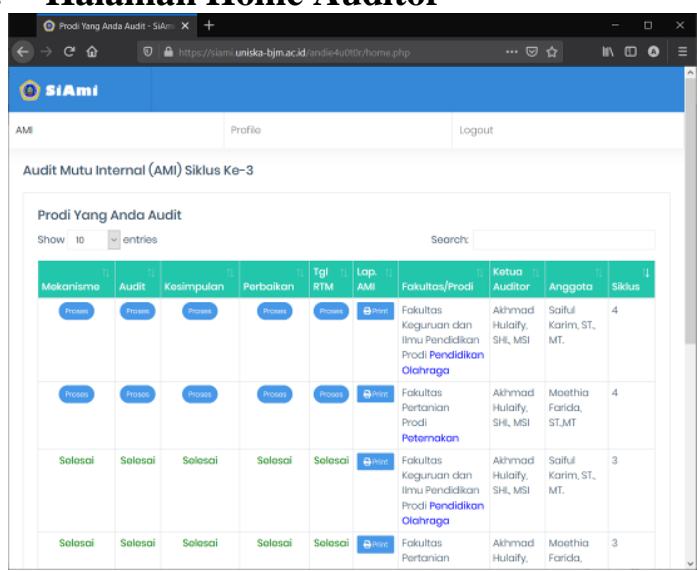

Gambar 17 Halaman Home Auditor

e. Halaman Home Auditee

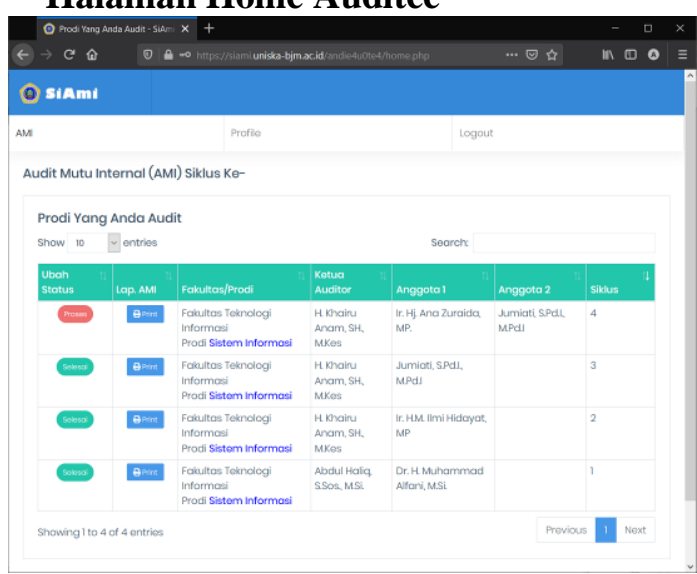

Gambar 18 Halaman Home Auditee

\section{f. Halaman Home Admin}

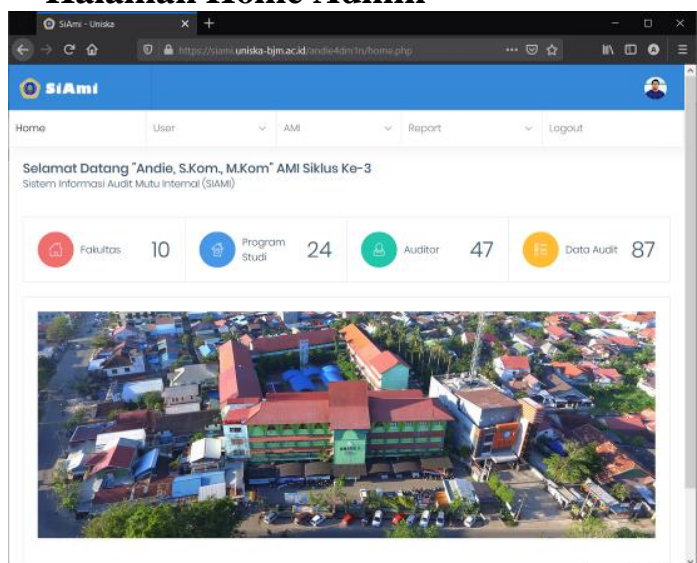

Gambar 19 Halaman Home Admin 


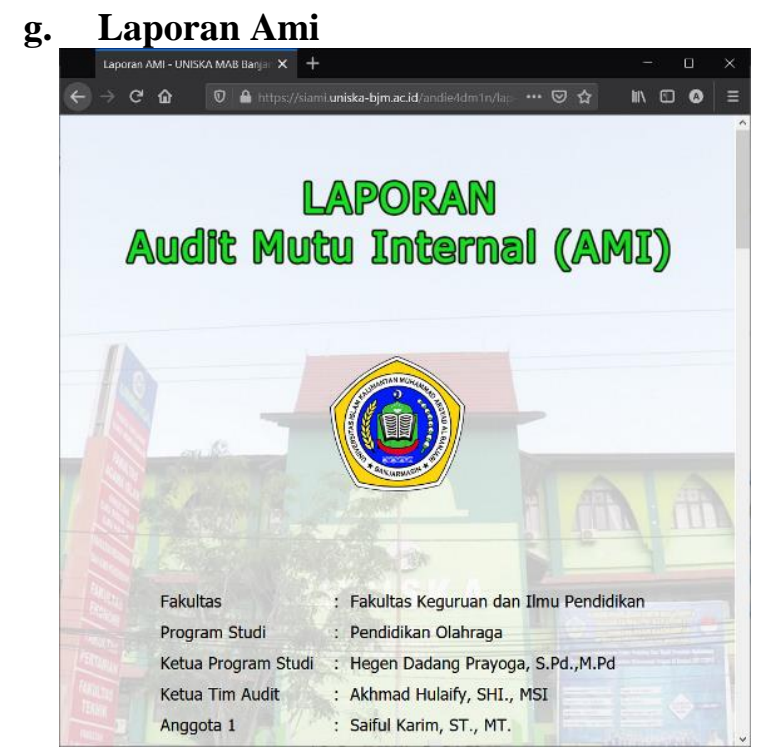

Gambar 20 Halaman Laporan AMI

\section{h. Rekap Temuan}

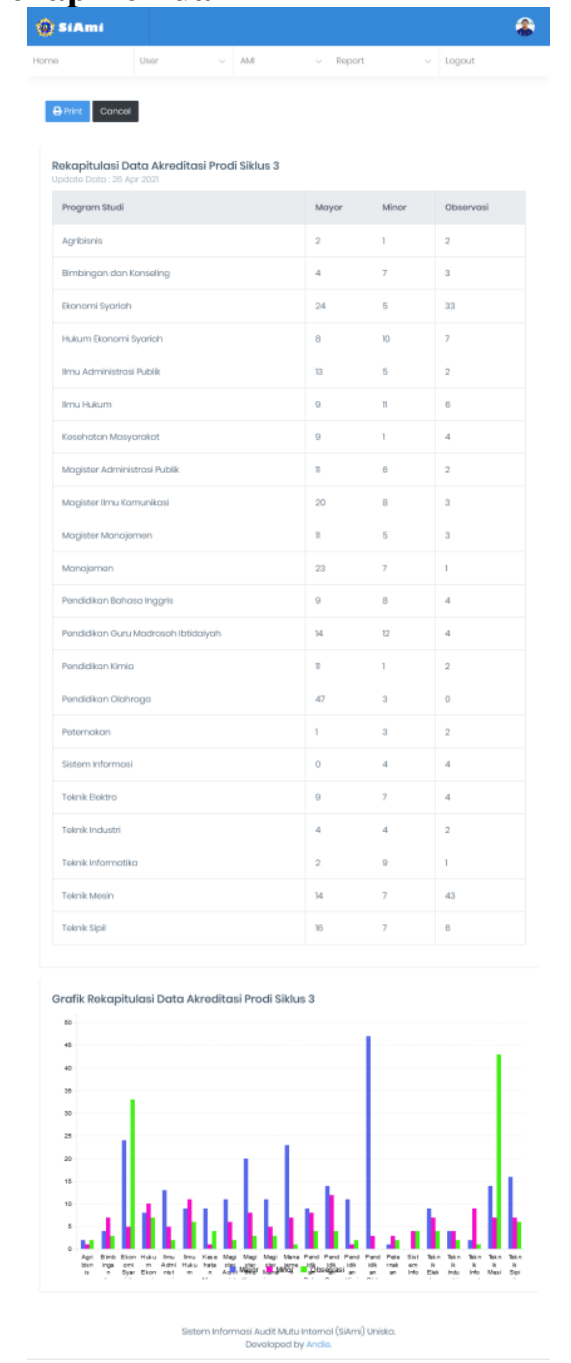

Gambar 21 Halaman Rekap Temuan

\section{i. Persentasi KTS}

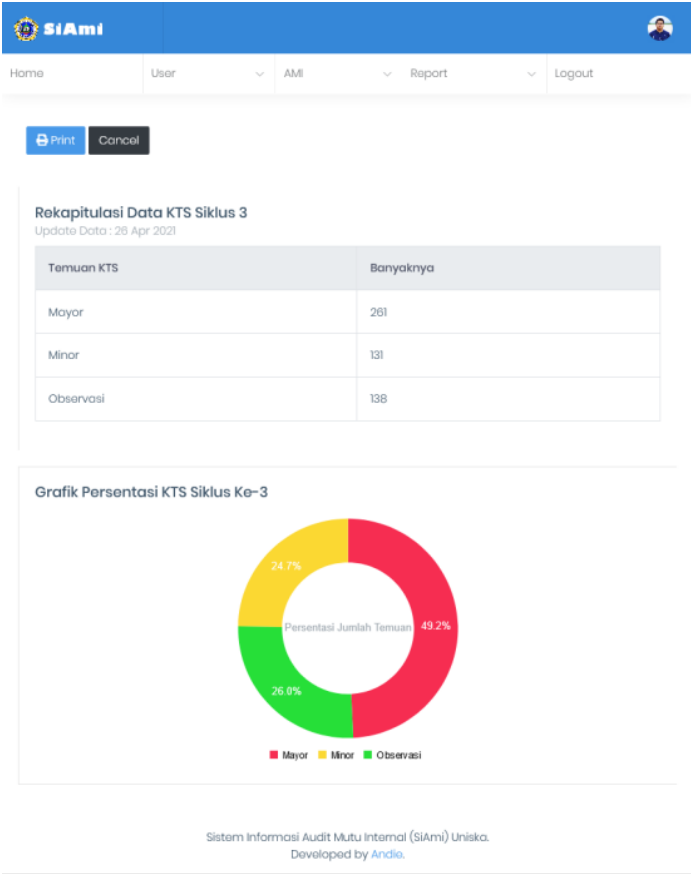

Gambar 22 Halaman Persentasi KTS

\section{PENGUJIAN SISTEM}

Pengujian dimana program tersebut dicoba dan di jalankan secara prabadi untuk memastikan telah dibuat bebas dari kesalahan (bug), walaupun tidak kemungkinan masih terjadi bug, namun pengujian ini setidaknya bisa meminilisir kesalahan yang akan terjadi. Pada tahap ini pengujian program menggunakan metode pengujian unit dengan pendekatan black-box testing. Pengujian secara black-box, yaitu suatu pendekatan untuk menguji setiap fungsi didalam program dengan benar. Berikut beberapa proses yang di lakukan, yaitu:

1. Fungsi-fungsi yang tidak benar, baik input maupun output

2. Kesalahan interface

3. Kesalahan database ataupun struktur akses database

Dibawah ini merupakan contoh tabel hasil pengujian dari Sistem Informasi Audit Mutu Internal (SIAMI) pada form Input temuan AMI:

Tabel 14 Hasil Pengujian Blackbox

\begin{tabular}{|l|l|l|l|}
\hline \multicolumn{4}{|c|}{ Kasus dan Hasil Uji } \\
\hline $\begin{array}{c}\text { Mata } \\
\text { naka }\end{array}$ & \multicolumn{1}{|c|}{ Yang } \\
Diharapkan & $\begin{array}{c}\text { Pengamata } \\
\mathbf{n}\end{array}$ & $\begin{array}{c}\text { Kesimpula } \\
\mathbf{n}\end{array}$ \\
\hline $\begin{array}{l}\text { Pilih } \\
\text { butir } \\
\text { standar }\end{array}$ & $\begin{array}{l}\text { Memilih butir } \\
\text { standar yang } \\
\text { sudah } \\
\text { disediakan, } \\
\text { apabila tidak }\end{array}$ & $\begin{array}{l}\text { Sesuai yang } \\
\text { diharapkan }\end{array}$ & Berhasil \\
\end{tabular}




\begin{tabular}{|c|c|c|c|}
\hline & $\begin{array}{l}\text { dipilih akan } \\
\text { muncul pesan } \\
\text { error bahwa } \\
\text { "Butir harus } \\
\text { dipilih" }\end{array}$ & & \\
\hline $\begin{array}{l}\text { Pilih } \\
\text { temuan } \\
\text { KTS }\end{array}$ & $\begin{array}{l}\text { Memilih temuan } \\
\text { KTS yang sudah } \\
\text { disediakan, } \\
\text { apabila tidak } \\
\text { dipilih akan } \\
\text { muncul pesan } \\
\text { error bahwa } \\
\text { "Temuan KTS } \\
\text { harus dipilih" }\end{array}$ & $\begin{array}{l}\text { Sesuai yang } \\
\text { diharapkan }\end{array}$ & Berhasil \\
\hline $\begin{array}{l}\text { Tulis } \\
\text { uraian } \\
\text { ketidak } \\
\text { sesuaian }\end{array}$ & $\begin{array}{l}\text { Menulis uraian } \\
\text { ketidaksesuaian } \\
\text { boleh lebih dari } \\
1 \text { baris atau } \\
\text { dikasih - saja, } \\
\text { apabila tidak } \\
\text { dipilih akan } \\
\text { muncul pesan } \\
\text { error } \\
\text { "Ketidaksesuaia } \\
\text { n harus diisi". }\end{array}$ & $\begin{array}{l}\text { Sesuai yang } \\
\text { diharapkan }\end{array}$ & Berhasil \\
\hline $\begin{array}{l}\text { Tulis } \\
\text { tindakan } \\
\text { perbaika } \\
\text { n }\end{array}$ & $\begin{array}{l}\text { Menulis uraian } \\
\text { tindakan } \\
\text { perbaikan boleh } \\
\text { lebih dari } 1 \text { baris } \\
\text { atau dikasih - } \\
\text { saja, apabila } \\
\text { tidak dipilih } \\
\text { akan muncul } \\
\text { pesan error } \\
\text { "Tindakan } \\
\text { perbaikan harus } \\
\text { diisi". }\end{array}$ & $\begin{array}{l}\text { Sesuai yang } \\
\text { diharapkan }\end{array}$ & Berhasil \\
\hline $\begin{array}{l}\text { Tulis } \\
\text { target } \\
\text { waktu } \\
\text { selesai }\end{array}$ & $\begin{array}{l}\text { Menulis target } \\
\text { waktu selesai } \\
\text { boleh lebih dari } \\
1 \text { baris atau } \\
\text { dikasih - saja, } \\
\text { apabila tidak } \\
\text { dipilih akan } \\
\text { muncul pesan } \\
\text { error "Target } \\
\text { waktu harus } \\
\text { diisi". }\end{array}$ & $\begin{array}{l}\text { Sesuai yang } \\
\text { diharapkan }\end{array}$ & Berhasil \\
\hline $\begin{array}{l}\text { Klik } \\
\text { tombol } \\
\text { simpan }\end{array}$ & $\begin{array}{l}\text { Akan } \\
\text { menyimpan } \\
\text { semua data yang } \\
\text { sudah di input }\end{array}$ & $\begin{array}{l}\text { Sesuai yang } \\
\text { diharapkan }\end{array}$ & Berhasil \\
\hline $\begin{array}{l}\text { Klik } \\
\text { tombol } \\
\text { Cancel }\end{array}$ & $\begin{array}{l}\text { Akan } \\
\text { membatalkan } \\
\text { semua isian dan } \\
\text { kembali ke } \\
\text { halaman } \\
\text { sebelumnya }\end{array}$ & $\begin{array}{l}\text { Sesuai yang } \\
\text { diharapkan }\end{array}$ & Berhasil \\
\hline $\begin{array}{l}\text { Klik } \\
\text { tombol } \\
\text { Edit }\end{array}$ & $\begin{array}{l}\text { Akan } \\
\text { menyimpan } \\
\text { hasil isian } \\
\text { perbaikan }\end{array}$ & $\begin{array}{l}\text { Sesuai yang } \\
\text { diharapkan }\end{array}$ & Berhasil \\
\hline $\begin{array}{l}\text { Klik } \\
\text { tombol }\end{array}$ & $\begin{array}{l}\text { Akan } \\
\text { menghapus }\end{array}$ & $\begin{array}{l}\text { Sesuai yang } \\
\text { diharapkan }\end{array}$ & Berhasil \\
\hline
\end{tabular}

\begin{tabular}{l|l|l|}
\hline Hapus & $\begin{array}{l}\text { semua data yang } \\
\text { telah disimpan }\end{array}$ & \\
\hline \\
IMPLEMENTASI SISTEM
\end{tabular}

Setelah semua sistem berjalan dengan normal maka akan dilaksanakan implementasi sistem ke pengguna atau user yang telah ditentukan yaitu Auditor, Auditee dan Admin. Semua proses akan dilaksanakan pada acara Audit Mutu Internal (AMI) siklus ke 5 yang akan dilaksanakan setelah Hari Raya Idul Fitri tahun 2021 atau sekitar bulan Juni 2021.

\section{KESIMPULAN}

Berikut beberapa point yang dapat kami simpulkan dalam pembuatan Sistem Informasi Audit Mutu Internal (SIAMI) :

a. Aplikasi dirancang menggunakan metode Waterfall yang meliputi, Analisa kebutihan sistem, desain sistem, implementasi sistem, pengujian sistem dan pemeliharaan sistem.

b. Aplikasi dibuat berbasis web dengan menggunakan bahasa pemrograman PHP dibantu oleh Adobe Dreamweaver 5.5 sebagai text editor, Bootstrap sebagai fremework CSS atau tampilan aplikasi dan MySQL sebagai pengelola databasenya.

c. Aplikasi dirancang menggunakan 3 level user yaitu Auditor, Auditee dan Admin.

d. Aplikasi dirancang khusus untuk pengguna di ruang lingkup Universitas Islam Kalimantan Muhammad Arsyad Al Banjari Banjarmasin, khususnya di Lembaga Penjaminan Mutu.

e. Aplikasi berjalan dengan lancar dan normal setelah di upload ke hosting Uniska dan dengan domain https://siami.uniskabjm.ac.id/

f. Hasil implementasi sistem terhadap pengguna secara keseluruhan adalah 90\% pengguna memilih penilaian Sangat Baik.

\section{REFERENSI}

[1] Andie, Hasanuddin, \& Fikri, I. (2018). Sistem Informasi Pusat Data Universitas (SIPUSDATAS). SEMINASTIKA, 78-84.

[2] Bunafit, N. (2005). Database Relasional dengan MySQL. Yogyakarta: Penerbit Andi.

[3] Darmawan, A., \& Hasibuan, M. S. (2014). Analisis dan Perancangan Aplikasi Sistem Informasi Audit Mutu Internal dan Dokumentasi Penjaminan Mutu Perguruan 
Tinggi. Jurnal Generic, Vol. 9, No. 2, 342347.

[4] Erawan, L. (2014). Dasar-Dasar PHP. Semarang: Universitas Dian Nuswantoro.

[5] Kadir, A. (2003). Pengenalan Sistem Informasi. Yogyakarta: Penerbit Andi.

[6] Komarudin, A., \& Pudjiantoro, T. H. (2018). Sistem Informasi Audit Mutu Internal Satuan Penjaminan Mutu (SPM) Unjani. SEINASI-KESI, 76-81.

[7] Pibriana, D., \& Ricoida, D. I. (2018). Analisis dan Perancangan Sistem Informasi Audit Mutu Internal Pada STMIK GI MDP. Seminar Nasional Teknologi Informasi dan Multimedia 2018, 67-72.

[8] Rudyanto, A. (2011). Pemrograman Web Dinamis Menggunakan PHP dan MySQL. Yogyakarta: Penerbit Andi.

[9] Sugiarta, I. K., Suasnawa, I. W., \& Saptarini, N. G. (2019). Perancangan Sistem Informasi Audit Mutu Internal Dengan Zahman Framework Studi Kasus Politeknik Negeri Bali. JURNAL SIMETRIK VOL.9, NO.1, 152-158.

[10] Sutabri, T. (2004). Analisa Sistem Informasi. Yogyakarta: Penerbit Andi.

[11] Tim, P. S. (2018). Pengertian Audit Mutu Internal (AMI). Jakarta: Kementerian Riset, Teknologi, dan Pendidikan Tinggi.

[12] Yanti, N. (2013). Sistem Informasi Audit Mutu Internal Universitas Islam Negeri Sultan Syarif Kasim Riau (Studi Kasus: Lembaga Penjaminan Mutu). Jurnal Coreit, 92-104. 